\title{
Effect of Land Configuration and Plant Spacing on Indian Bean Dolichos lablab (PAPADI)
}

\author{
Abdul Mosawer Niazi ${ }^{1}$, Naresh Chaudhari ${ }^{2 *}$ and H.M. Virdia ${ }^{3}$ \\ ${ }^{1}$ M.Sc. Agronomy (Student), N.M. College of Agriculture, Navsari Agricultural University, Navsari, Gujarat, India \\ ${ }^{2}$ Senior Research Fellow, Main Sugarcane Research Station, Navsari Agricultural University, Navsari, Gujarat, India \\ ${ }^{3}$ Research Scientist, Main Sugarcane Research Station, Navsari Agricultural University, Navsari, Gujarat, India \\ *Corresponding author: nareshchaudhari951@gmail.com
}

Received: $24-03-2021$

Revised: 04-05-2021

Accepted: 09-06-2021

\begin{abstract}
The field experiment was conducted to study of land configuration and plant spacing on Indian bean Dolichos lablab (Papadi) under south Gujarat condition. The experiment was laid out in split plot design, total twelve treatments of land configuration, intra row and row spacing with three replication. All the growth characters yield attributes, yield as well as nutrient uptake not affected by different land configuration and intra row spacing. While, $30 \mathrm{~cm}$ row spacing recorded significantly higher plant population, plant height as well as yield attributes and yield of Indian bean viz., seed index, seed yield, stover yield and harvest index. While, number of branches per plant, dry matter accumulation, days to $50 \%$ percent flowering, number of pod per plant, number of seeds per pod and seed yield per plant were recorded higher with the treatment $60 \mathrm{~cm}$ row spacing. Crude protein content and nutrient content of crop not affected by different treatments. While seed and stover yield was significantly higher with 30 $\mathrm{cm}$ row spacing and remain at par with $45 \mathrm{~cm}$ row spacing. The percentage of seed yield increased with $30 \mathrm{~cm}$ row spacing was 24.28 and 59.52 as compare to $45 \mathrm{~cm}$ and $60 \mathrm{~cm}$ row spacing, respectively. The highest economic net returns of ₹ 100553/ha with benefit cost ratio of 3.40 were realized when Indian bean crop sown at $30 \mathrm{~cm}$ row spacing.
\end{abstract}

Keywords: Economic, India bean, land configuration, Protein and Row spacing

Pulses are the important crop and important part of Indian dietary for crude protein supplement in our country. More than half of Indian population is vegetarian and such people cannot afford very expensive animal crude protein. The crude protein from pulses is easily digestible, relatively cheaper and has higher biological values. Legumes are vital in agriculture as they form associations with bacteria that fix-nitrogen from atmosphere. Thousands of legume species exist but more common beans (Phaseolus vulgaris L.) are eaten more than any other. In some countries such as Mexico and Brazil, beans are the primary source of crude protein in human diets. Pulses are indispensable source of crude protein for predominately vegetarian population of our country (Broughton et al. 2003).
Crop production in such soils is constrained by soil physical and hydrological properties. Low infiltration, poor internal drainage, narrow workable moisture range, inadequate seeding emergence and loss of soil structure, low organic matter, high cation exchange capacity and alkaline reaction are some of the properties associated with such soils. Poor yield potentiality of Indian bean may be due to poor management practices as it was constantly grown under marginal lands, residual moisture or stress conditions by the farmers. The

\footnotetext{
How to cite this article: Niazi, A.M., Chaudhari, N. and Virdia, H.M. (2021). Effect of Land Configuration and Plant Spacing on Indian Bean Dolichos lablab (PAPADI). International Journal of Bioresource Science, 08(01): 29-33.
}

Source of Support: None; Conflict of Interest: None

क्ष 
improved agro-techniques play a vital role in sustaining crop yields. Adequate plant population is most important to harvest full yield potential of this crop. It is also indispensable that the plant population should not only be defined in terms of number of plants per unit area, but also in terms of arrangement of these plants in the field viz., row and plant spacing. In general, too narrow spacing increases the competition for space, nutrients, light and moisture whereas, wider spacing increases the weed problem ultimately reduces the crop yield. Optimum spacing fosters the problem of intraplant competition, cooperative and competitive interactions. Considering the above facts and views, the present experiment "Effect of land configuration and plant spacing on Indian bean Dolichos lablab (Papadi) under south Gujarat condition" was conducted.

\section{MATERIALS AND METHODS}

A field experiment was carried out during the rabi season of the year 2019-20 on Plot No. 23, Block-C of College Farm, N.M. College of Agriculture, Navsari Agricultural University, Navsari (Gujarat).Total twelve treatments combinations consisting of two levels of land configuration (Raised bed; flatbed) and two levels of intra row spacing $(20 \mathrm{~cm} ; 30 \mathrm{~cm})$ as main plot treatments with three levels of row spacing $(30 \mathrm{~cm} ; 45 \mathrm{~cm} ; 60 \mathrm{~cm}$ )as sub plot treatments were tried in split plot design with three replication. The rabi Indian bean (Papadi) variety GBIN 22 was sown in December, 2019 and finally harvested in February, 2020. The crop was fertilized with $20 \mathrm{~kg}$ $\mathrm{N}-40 \mathrm{~kg} \mathrm{P}_{2} \mathrm{O}_{5}$ ha with 5 tones of farm yard manure. The soil of the experimental field was clayey in texture and with low in available nitrogen, medium in available phosphorus and high in available potassium, slightly alkaline in reaction with normal electrical conductivity. The weather conditions were favorable for crop growth and there was no severe infestation of any pest and diseases during the course of investigation. All other cultural practices were performed uniformly for all the treatments. At time of observation, various parameters was taken in experiment with using standard procedures. The significance of difference was tested by ' $F$ ' test and five per cent level of significance was used to test the significance of results describe by Panse and Sukhatme (1967).

\section{RESULTS AND DISCUSSION}

\section{Growth parameters}

Among the various parameters presented in Table 1 indicted that land configuration not showed significant effect on the plant height of Indian bean at 20 days after sowing ad at harvest. Significantly higher plant population (252 plot $\left.^{-1}\right)$ was found with $20 \mathrm{~cm}$ intra row spacing $\left(\mathrm{I}_{1}\right)$ while significantly lower plant population $\left(170\right.$ plot $\left.^{-1}\right)$ was with $30 \mathrm{~cm}$ intra row spacing $\left(\mathrm{I}_{2}\right)$. While row spacing, plant population at 20 days after sowing was significantly higher with treatment $R_{1}$ ( $30 \mathrm{~cm}$ row spacing) while lowest plant population was recorded with wider row spacing $\left(\mathrm{R}_{3^{\prime}}, 60 \mathrm{~cm}\right)$ it due to difference of plant spacing.

The data furnished in Table 1 indicated that land configuration and intra row spacing was not showed significant effect on the plant height, number of branches per plant, dry matter per plant and days to $50 \%$ flowering of Indian bean at 30, 60 days after sowing and at harvest. However, significantly higher plant $(19.51 \mathrm{~cm}, 56.81 \mathrm{~cm}$ and $57.321 \mathrm{~cm})$ was recorded with treatment $R_{1}$ (30 cm row spacing) at 30 DAS, 60 DAS and at harvest. While number of branches per plant $(5.25,8.24$ and 8.31$)$ was recorded significantly higher with wider row spacing of 60 $\mathrm{cm}\left(\mathrm{R}_{3}\right)$. The data regarding dry matter, treatment $\mathrm{R}_{3}$ (60 $\mathrm{cm}$ row spacing) was recorded significantly higher dry matter accumulation at 30 DAS, 60 DAS and at harvest. Similar trend also recorded in days to 50 percent flowering of Indian bean. This might be due to higher competition for space, moisture, light, nutrients taller plant under narrow plant geometry due to higher absorption and utilization of nitrogen and other plant nutrient, rapid meristemestic activity and growth in term of plant height. The results corroborate the results of Patel et al. (2010) for moth bean crop.

\section{Yield attributes and yield}

The mean data presented in table 2 and results not showed any significantly effect of various yield and yield attributing characters of Indian bean at harvest due to various land configuration and intra plant spacing treatments. Crude protein content of Indian bean also found non-significant.

Among the different row spacing levels tested, 30 $\mathrm{cm}$ row spacing recorded significantly higher yield 
Table 1: Effect of land configuration and spacing on growth characters of Indian bean crop

\begin{tabular}{|c|c|c|c|c|c|c|c|c|c|c|c|c|}
\hline \multirow{2}{*}{ Treatments } & \multicolumn{2}{|c|}{$\begin{array}{c}\text { Plant } \\
\text { Population } \\
\text { (per net plot) }\end{array}$} & \multicolumn{2}{|c|}{$\begin{array}{l}\text { Plant height } \\
(\mathrm{cm})\end{array}$} & \multicolumn{3}{|c|}{$\begin{array}{c}\text { Number of branches } \\
\text { per plant }\end{array}$} & \multicolumn{4}{|c|}{$\begin{array}{l}\text { Dry matter accumulation } \\
\qquad\left(\text { g plant }^{-1}\right)\end{array}$} & \multirow{2}{*}{$\begin{array}{l}\text { Days } \\
\text { to } 50 \% \\
\text { flowering }\end{array}$} \\
\hline & $\begin{array}{l}20 \\
\text { DAS }\end{array}$ & Harvest & $\begin{array}{l}30 \\
\text { DAS }\end{array}$ & $\begin{array}{l}60 \\
\text { DAS }\end{array}$ & Harvest & $\begin{array}{l}30 \\
\text { DAS }\end{array}$ & $\begin{array}{l}60 \\
\text { DAS }\end{array}$ & Harvest & $\begin{array}{l}30 \\
\text { DAS }\end{array}$ & $\begin{array}{l}60 \\
\text { DAS }\end{array}$ & Harvest & \\
\hline \multicolumn{13}{|c|}{ Main plot $(\mathrm{C} \times \mathrm{I})$} \\
\hline \multicolumn{13}{|c|}{ Land Configuration (C) } \\
\hline $\mathrm{C}_{1}:$ Raised bed & 211 & 201 & 18.98 & 54.36 & 55.39 & 4.77 & 7.71 & 7.88 & 8.45 & 18.07 & 24.21 & 50.28 \\
\hline $\mathrm{C}_{2}:$ Flatbed & 211 & 201 & 18.69 & 53.80 & 53.91 & 4.55 & 7.41 & 7.61 & 8.23 & 17.23 & 23.18 & 50.78 \\
\hline SEm \pm & 5.52 & 5.57 & 0.46 & 1.23 & 1.61 & 0.09 & 0.19 & 0.18 & 0.20 & 0.34 & 0.75 & 1.29 \\
\hline $\mathrm{CD}(\mathrm{P}=0.05)$ & NS & NS & NS & NS & NS & NS & NS & NS & NS & NS & NS & NS \\
\hline \multicolumn{13}{|c|}{ Intra row spacing (I) } \\
\hline $\mathrm{I}_{1}: 20 \mathrm{~cm}$ & 252 & 242 & 19.09 & 54.83 & 55.86 & 4.49 & 7.23 & 7.52 & 8.12 & 16.87 & 22.77 & 50.17 \\
\hline $\mathrm{I}_{2}: 30 \mathrm{~cm}$ & 170 & 160 & 18.58 & 53.33 & 53.44 & 4.82 & 7.89 & 7.97 & 8.57 & 18.43 & 24.63 & 50.89 \\
\hline SEm \pm & 5.52 & 5.57 & 0.46 & 1.23 & 1.61 & 0.09 & 0.19 & 0.18 & 0.20 & 0.35 & 0.75 & 1.29 \\
\hline $\mathrm{CD}(\mathrm{P}=0.05)$ & 19. & 19 & NS & NS & NS & 0.30 & 0.67 & NS & NS & 1.05 & NS & NS \\
\hline $\mathrm{CV} \%$ & 11.08 & 11.77 & 10.47 & 9.63 & 12.48 & 8.01 & 10.80 & 9.74 & 10.20 & 12.25 & 13.44 & 11.52 \\
\hline \multicolumn{13}{|l|}{ Sub plot (R) } \\
\hline \multicolumn{13}{|c|}{ Row spacing (R) } \\
\hline $\mathrm{R}_{1}: 30 \mathrm{~cm}$ & 293 & 283 & 19.51 & 56.81 & 57.32 & 4.08 & 6.93 & 7.25 & 7.70 & 15.06 & 20.26 & 49.83 \\
\hline $\mathrm{R}_{2}: 45 \mathrm{~cm}$ & 195 & 185 & 18.68 & 54.51 & 55.41 & 4.65 & 7.31 & 7.68 & 8.30 & 18.16 & 23.62 & 50.58 \\
\hline $\mathrm{R}_{3}: 60 \mathrm{~cm}$ & 146 & 135 & 18.32 & 50.92 & 51.23 & 5.25 & 8.24 & 8.31 & 9.03 & 19.74 & 27.22 & 51.17 \\
\hline SEm \pm & 4.80 & 4.89 & 0.45 & 1.24 & 1.32 & 0.09 & 0.21 & 0.21 & 0.21 & 0.27 & 0.80 & 0.79 \\
\hline $\mathrm{CD}(\mathrm{P}=0.05)$ & 14 & 15 & NS & 3.71 & 3.95 & 0.26 & 0.62 & 0.64 & 0.62 & 0.84 & 2.41 & NS \\
\hline $\mathrm{CV} \%$ & 9.59 & 8.43 & 8.31 & 7.93 & 8.35 & 6.33 & 9.42 & 9.53 & 8.56 & 8.10 & 11.73 & 5.73 \\
\hline
\end{tabular}

Table 2: Effect of land configuration and spacing on yield attributes, yield and economic of Indian bean crop

\begin{tabular}{|c|c|c|c|c|c|c|c|c|c|c|c|c|}
\hline Treatments & $\begin{array}{l}\text { Number of } \\
\text { pods per } \\
\text { plant }\end{array}$ & $\begin{array}{l}\text { Number of } \\
\text { seeds per } \\
\text { pod }\end{array}$ & $\begin{array}{l}\text { Seed } \\
\text { index } \\
\text { (g) }\end{array}$ & $\begin{array}{l}\text { Seed } \\
\text { yield per } \\
\text { plant (g) }\end{array}$ & $\begin{array}{l}\text { Seed } \\
\text { yield } \\
\left(\mathrm{kg} \mathrm{ha}^{-1}\right)\end{array}$ & $\begin{array}{l}\text { Stover } \\
\text { yield } \\
\left(\mathrm{kg} \mathrm{ha}^{-1}\right)\end{array}$ & $\begin{array}{l}\text { Harvest } \\
\text { index }\end{array}$ & $\begin{array}{l}\text { Protein } \\
\text { Content } \\
(\%)\end{array}$ & $\begin{array}{l}\text { Protein } \\
\text { Yield } \\
\left(\mathrm{kg} \mathrm{ha}^{-1}\right)\end{array}$ & $\begin{array}{l}\text { Gross } \\
\text { return } \\
\text { (₹ ha) }\end{array}$ & $\begin{array}{l}\text { Net } \\
\text { return } \\
\text { (₹ ha) }\end{array}$ & $\begin{array}{l}\mathrm{B}: \mathrm{C} \\
\text { ratio }\end{array}$ \\
\hline \multicolumn{13}{|c|}{ Main plot (C x I) } \\
\hline $\mathrm{C}_{1}$ :Raised bed & 20.25 & 3.17 & 12.88 & 7.03 & 1073 & 3099 & 25.73 & 24.54 & 263.01 & 113439 & 74030 & 2.85 \\
\hline $\mathrm{C}_{2}:$ Flatbed & 21.09 & 3.22 & 13.08 & 6.97 & 1058 & 2960 & 26.33 & 24.29 & 256.21 & 111672 & 72563 & 2.84 \\
\hline \multicolumn{13}{|c|}{ Intra row spacing (I) } \\
\hline $\mathrm{I}_{1}: 20 \mathrm{~cm}$ & 20.25 & 3.17 & 12.88 & 6.69 & 1128 & 3111 & 26.61 & 24.49 & 275.70 & 119027 & 78568 & 2.91 \\
\hline $\mathrm{I}_{2}: 30 \mathrm{~cm}$ & 21.09 & 3.22 & 13.08 & 7.06 & 1002 & 2948 & 25.37 & 24.35 & 243.51 & 106083 & 68025 & 2.78 \\
\hline SEm \pm & 0.56 & 0.10 & 0.38 & 0.17 & 155 & 80 & 2.70 & 0.06 & 37.22 & - & - & - \\
\hline $\mathrm{CD}(\mathrm{P}=0.05)$ & NS & NS & NS & NS & NS & NS & NS & NS & NS & - & - & - \\
\hline \multicolumn{13}{|l|}{ Sub plot (R) } \\
\hline $\mathrm{R}_{1}: 30 \mathrm{~cm}$ & 19.39 & 3.00 & 12.63 & 6.41 & 1356 & 3299 & 29.12 & 24.48 & 331.20 & 142172 & 100553 & 3.40 \\
\hline $\mathrm{R}_{2}: 45 \mathrm{~cm}$ & 20.00 & 3.17 & 13.05 & 6.73 & 1091 & 2965 & 26.90 & 24.32 & 265.09 & 104940 & 66201 & 2.71 \\
\hline $\mathrm{R}_{3}: 60 \mathrm{~cm}$ & 22.62 & 3.42 & 13.26 & 7.48 & 850 & 2825 & 23.12 & 24.44 & 207.71 & 90554 & 53136 & 2.42 \\
\hline SEm \pm & 0.56 & 0.11 & 0.38 & 0.17 & 107 & 65 & 1.99 & 0.12 & 25.47 & - & - & - \\
\hline $\mathrm{CD}(\mathrm{P}=0.05)$ & 1.67 & NS & NS & 0.52 & 320 & 193 & 5.98 & NS & 76.30 & - & - & - \\
\hline $\mathrm{CV} \%$ & 9.32 & 12.24 & 8.14 & 8.71 & 9.85 & 7.36 & 9.56 & 1.10 & 8.99 & - & - & - \\
\hline
\end{tabular}

Price of input: (a) Seed cost: ₹ $480 \mathrm{~kg}^{-1}$; (b) Labour charge: ₹ 268 day-1: (c) Price of produce: (i) Seed - Stover : ₹ 100 - $2 \mathrm{~kg}^{-1}$; (d) Fertilizers: (i) $\mathrm{N}$ : ₹ $11.65 \mathrm{~kg}^{-1}$ : (ii) $\mathrm{P}_{2} \mathrm{O}_{5}$ : ₹ $45.25 \mathrm{~kg}^{-1}$. 
Table 3: Effect of land configuration and spacing on nutrient content and uptake of Indian bean crop

\begin{tabular}{|c|c|c|c|c|c|c|c|c|c|c|c|c|c|c|c|}
\hline \multirow[t]{2}{*}{ Treatments } & \multicolumn{3}{|c|}{$\begin{array}{l}\text { Nutrient content in } \\
\text { grain }(\%)\end{array}$} & \multicolumn{3}{|c|}{$\begin{array}{l}\text { Nutrient content } \\
\text { in stover }(\%)\end{array}$} & \multicolumn{3}{|c|}{$\begin{array}{l}\text { Nutrient uptake in } \\
\text { grain }(\mathrm{kg} / \mathrm{ha})\end{array}$} & \multicolumn{3}{|c|}{$\begin{array}{l}\text { Nutrient uptake in } \\
\text { stover }(\mathrm{kg} / \mathrm{ha})\end{array}$} & \multicolumn{3}{|c|}{$\begin{array}{l}\text { Total nutrient } \\
\text { uptake by crop }(\mathrm{kg} / \\
\text { ha) }\end{array}$} \\
\hline & $\mathbf{N}$ & $\mathbf{P}$ & $\mathbf{K}$ & $\mathbf{N}$ & $\mathbf{P}$ & K & $\mathbf{N}$ & $\mathbf{P}$ & K & $\mathbf{N}$ & $\mathbf{P}$ & K & $\mathbf{N}$ & $\mathbf{P}$ & K \\
\hline \multicolumn{16}{|c|}{ Main plot $(C \times I)$} \\
\hline \multicolumn{16}{|c|}{ Land Configuration (C) } \\
\hline $\mathrm{C}_{1}$ : Raised bed & 3.93 & 0.202 & 0.097 & 2.43 & 0.227 & 2.26 & 42.08 & 2.07 & 1.02 & 75.11 & 7.06 & 69.84 & 117.19 & 9.14 & 70.86 \\
\hline $\mathrm{C}_{2}$ : Flatbed & 3.89 & 0.199 & 0.096 & 2.44 & 0.222 & 2.28 & 40.99 & 2.06 & 1.02 & 72.15 & 6.59 & 66.33 & 113.14 & 8.65 & 67.35 \\
\hline SEm \pm & 0.01 & 0.002 & 0.002 & 0.02 & 0.002 & 0.08 & 5.96 & 0.30 & 0.16 & 1.65 & 0.17 & 1.86 & 5.67 & 0.30 & 1.96 \\
\hline $\mathrm{CD}(\mathrm{P}=0.05)$ & NS & NS & NS & NS & NS & NS & NS & NS & NS & NS & NS & NS & NS & NS & NS \\
\hline \multicolumn{16}{|c|}{ Intra row spacing (I) } \\
\hline $\mathrm{I}_{1}: 20 \mathrm{~cm}$ & 3.92 & 0.201 & 0.097 & 2.43 & 0.223 & 2.23 & 44.11 & 2.19 & 1.08 & 75.41 & 7.14 & 68.90 & 119.52 & 9.34 & 69.98 \\
\hline$\underline{\mathrm{I}_{2}}: 30 \mathrm{~cm}$ & 3.90 & 0.199 & 0.096 & 2.44 & 0.221 & 2.31 & 38.96 & 1.94 & 0.96 & 71.85 & 6.59 & 67.27 & 110.81 & 8.45 & 68.23 \\
\hline SEm \pm & 0.01 & 0.002 & 0.002 & 0.02 & 0.002 & 0.08 & 5.96 & 0.30 & 0.16 & 1.65 & 0.18 & 1.86 & 5.67 & 0.30 & 1.96 \\
\hline $\mathrm{CD}(\mathrm{P}=0.05)$ & NS & NS & NS & NS & NS & NS & NS & NS & NS & NS & NS & NS & NS & NS & NS \\
\hline $\mathrm{CV} \%$ & 1.10 & 4.69 & 11.56 & 2.97 & 3.659 & 15.88 & 10.83 & 11.53 & 15.82 & 9.53 & 10.53 & 11.61 & 20.87 & 14.10 & 11.84 \\
\hline \multicolumn{16}{|l|}{ Sub plot (R) } \\
\hline \multicolumn{16}{|c|}{ Row spacing (R) } \\
\hline $\mathrm{R}_{1}: 30 \mathrm{~cm}$ & 3.92 & 0.199 & 0.098 & 2.41 & 0.226 & 2.26 & 52.96 & 2.46 & 1.29 & 79.47 & 7.82 & 73.86 & 132.43 & 10.28 & 74.68 \\
\hline $\mathrm{R}_{2}: 45 \mathrm{~cm}$ & 3.89 & 0.195 & 0.095 & 2.44 & 0.224 & 2.29 & 38.41 & 1.93 & 0.94 & 72.36 & 6.64 & 67.51 & 110.77 & 8.57 & 68.45 \\
\hline $\mathrm{R}_{3}: 60 \mathrm{~cm}$ & 3.91 & 0.192 & 0.095 & 2.45 & 0.223 & 2.26 & 33.23 & 1.80 & 0.84 & 69.05 & 6.03 & 62.89 & 102.28 & 7.83 & 64.18 \\
\hline $\mathrm{SEm} \pm$ & 0.02 & 0.002 & 0.003 & 0.02 & 0.002 & 0.08 & 4.08 & 0.20 & 0.15 & 1.30 & 0.15 & 1.73 & 4.36 & 0.27 & 1.67 \\
\hline $\mathrm{CD}(\mathrm{P}=0.05)$ & NS & NS & NS & NS & NS & NS & 12.22 & NS & NS & 3.90 & 0.46 & 5.18 & 13.73 & 0.80 & 4.99 \\
\hline $\mathrm{CV} \%$ & 1.64 & 3.85 & 8.31 & 2.22 & 2.92 & 12.91 & 3.99 & 3.13 & 4.23 & 6.12 & 7.85 & 8.80 & 13.11 & 10.33 & 8.22 \\
\hline
\end{tabular}

attributes and yield of Indian bean viz., seed index (13.26 g), seed yield (1356 kg/ha), stover yield (3299 $\mathrm{kg} / \mathrm{ha}$ ) and harvest index (29.12). While, number of pod per plant (22.62), number of seeds per pod (3.42) and seed yield per plant $(7.48 \mathrm{~g})$ were recorded higher with the treatment $60 \mathrm{~cm}$ row spacing. The higher seed yield of papadi was recorded with narrow row spacing $(30 \mathrm{~cm})$ and remain at par with $45 \mathrm{~cm}$ row spacing. The percentage of seed yield increased with $30 \mathrm{~cm}$ row spacing was 24.28 and 59.52 as compare to $45 \mathrm{~cm}$ and $60 \mathrm{~cm}$ row spacing, respectively. The better yield of various crop on raised bed/BBF also reported by Pilbean et al. (1989) and Ihsanuallah et al. (2002). Spacing play important role for the performance of the plant in the field and it depend on plant type and there compatibility. The narrow spaced crop either with inter or intra row spacing reported higher yield per area, may be due to cumulative effect of individual plant and yield equilibrium in yield reduction per plant under narrow spacing may compensated with more number of plants per unit area. Yield attributes per plant viz., Number of pods per plant, seeds per pod, seed index, seed yield per plant were recorded higher with wider spaced plants may be due to less competition among plants for the growth factors, which improve growth of individual plant, may resulted in more yield attributing values with the wider spaced crops, but per unit area it fail to produce cumulative higher yield. Similar result with the various crops also reported by Rasul et al. (2012).

\section{Protein quality}

The data in table 2 showed that different land configuration and spacing not showed any significant effect on crude protein content in grain. While crude protein yield $(331.20 \mathrm{~kg} / \mathrm{ha})$ was recorded significantly higher in treatment $R_{1}(30 \mathrm{~cm})$ due to significant variation in yield of seed (Table 2) of Indian bean, not by crude protein content in seed. Similar research also reported higher crude protein yield Chaudhari and Patel (2016) in pearl millet crop.

\section{Nutrient content and uptake}

Data pertaining to nitrogen, phosphorus and 
potassium content by Indian bean presented in Table 3 revealed that the difference in various treatments was found to be non- significant with nitrogen, phosphorus and potassium content in seeds and stover of Indian bean respect to land configuration, intra plant spacing and row spacing. However, nitrogen, phosphorus, potassium uptake and total uptake by the plant was recorded significantly higher with plant sown at narrow row space $(30 \mathrm{~cm})$. Nutrient uptake have some effect due to spacing treatments and it was only due to higher growth and yield of the crop in these treatments, which improve the uptake of the nutrient by plant as dry matter and other plant part volume increase it will reflected with uptake of the nutrient per unit area.

\section{Economic}

Data presented in Table 2 and showed higher net realization of ₹ 74030/ha and benefit cost ratio of 2.85 were recorded with raised bed land configuration in Indian bean. While higher net realization of ₹ 78568/ha and cost benefit ratio of 2.91 were obtained with treatment narrow intra row spacing $(20 \mathrm{~cm})$, and $30 \mathrm{~cm}$ intra row spacing net realization was ₹ 68025/ha and cost benefit ratio of 2.78 . However, highest economic net returns of ₹ 100553/ ha with benefit cost ratio of 3.40 were realized when Indian bean crop sown at $30 \mathrm{~cm}$ row spacing. The present findings are in close agreement with the results obtained by Chaniyara et al. (2002).

\section{CONCLUSION}

On the basis of experimental results, it can be concluded that Indian bean sown on raised bed or flatbed have no significant difference. Further, for getting higher profitable yield of Indian bean (Papadi) it should be sown with $45 \times 30 \mathrm{~cm}$ spacing under south Gujarat condition.

\section{REFERENCES}

1. Broughton, W.J., Hernandez, G., Blair, M., Beebe, S., Gepts, P. and Vanderleyden, J. 2003. Beans (Phaseolus spp.) model food legumes. Plant and Soil., 252(1): 55-128.

2. Chaniyara, N.J., Solanki, R.M. and Bhalu, V.B. 2002. Effect of inter and intra row spacing's on yield of mustard. Agricultural Science Digest, 22(1): 48-50.

3. Chaudhari, N.N. and Patel, D.D. 2017. Effect of integrated nitrogen management on productivity,quality of pearl millet and soil fertility of clay soils under south Gujarat conditions. Research on Crop, 18(2): 219-224.

4. Ihsanullah, F., Hayat, T., Habib, A., Abdul, B. and Noor, U. 2002. Effect of row spacing on agronomic traits and yield of Mung Bean (Vigna radiata L. Wilczek). Asian Journal of Plant Science, 1: 328-329.

5. Panse, V.G. and Sukhatme, P.V. 1967. "Statistical methods for agricultural workers. Indian Council of Agricultural Research, New Delhi.

6. Patel, M.M., Patel, I.C., Patel, P.H., Patel, R.I., Vaghela, S.G. and Acharya, S. 2010. Effect of sowing time, row spacing and seed rate on yield of moth bean under rain fed condition. Journal of Agri-legumes, 7(2): 112-114.

7. Pilbeam, C.J., Hebblethwaite, P.D. and Clark, A.S. 1989. Effect of different inter-row spacing's on faba beans of different form. Field Crops Research, 21(3-4): 203-214.

8. Rasul, F., Cheema, M.A., Sattar, A., Saleem, M.F. and Wahid, M.A. 2012. Evaluating the performance of three mung bean varieties grown under varying inter-row spacing. Journal Anim. Plant Science, 22(4): 1030-1035. 
